\title{
Clostridium acetireducens sp. nov., a Novel Amino Acid- Oxidizing, Acetate-Reducing Anaerobic Bacterium
}

\author{
JÓHANN ÖRLYGSSON, ${ }^{1 *}$ JANNEKE KROONEMAN, ${ }^{1}$ MATTHEW D. COLLINS, ${ }^{2}$ \\ CHRISTINA PASCUAL, ${ }^{2}$ AND JAN C. GOTTSCHAL ${ }^{1}$ \\ Department of Microbiology, University of Groningen, 9751 NN Haren, The Netherlands, ${ }^{1}$ and Institute \\ of Food Research, Reading Laboratory, Earley Gate, Reading RG6 2EF, United Kingdom ${ }^{2}$
}

\begin{abstract}
Strain $30 \mathrm{~A}^{\mathrm{T}}$ ( $\mathrm{T}=$ type strain), which was isolated from an anaerobic bioreactor fed on waste from a potato starch factory in De Krim, The Netherlands, is a nonmotile, gram-positive, anaerobic, rod-shaped organism that is able to degrade various amino acids, including alanine, leucine, isoleucine, valine, serine, and threonine. Acetate is required as an electron acceptor for the utilization of alanine, valine, leucine, and isoleucine. Other growth substrates, including pyruvate, $\alpha$-ketobutyrate, $\alpha$-ketoisocaproate, $\alpha$-keto-3-methylvalerate, $\alpha$-ketoisovalerate, and peptone, are intermediates in amino acid catabolism. Strain $30 \mathrm{~A}^{\mathbf{T}}$ utilizes neither the branched-chain amino acids nor alanine via interspecies hydrogen transfer with methanogenic and sulfatereducing bacteria or via the Stickland reaction with proline or glycine as an electron acceptor. No growth occurs with the following electron acceptors: fumarate, nitrate, nitrite, sulfite, sulfate, and oxygen. Yeast extract is required for growth. Sugars are not degraded. The optimal temperature and optimal pH for growth are 39 to $43^{\circ} \mathrm{C}$ and 6.4 to 7.6 , respectively. The results of a 16S rRNA sequence analysis phylogenetically placed strain $30 \mathrm{~A}^{\mathrm{T}}$ in Clostridium group I (genus Clostridium sensu stricto), where it forms a new and distinct line of descent.
\end{abstract}

In most investigations of anaerobic degradation of amino acids the workers have focused on fermentation by Clostridium species $(1,3,9,10,17,27,28)$. Studies performed with species of several other genera (viz., the genera Peptostreptococcus [4, 42], Campylobacter [22, 31], Acidaminobacter [39], Megasphaera [41], Eubacterium [12, 45], and Selenomonas [15, 32]), most of which are members of the low- $\mathrm{G}+\mathrm{C}$-content Clostridium subphylum of the gram-positive bacteria, have also contributed to our knowledge of anaerobic metabolism of amino acids.

Several workers have reported that in addition to the usual end products produced during fermentation of amino acids (i.e., carbon dioxide, volatile fatty acids, and ammonia), hydrogen is formed $(3,4,15,39,42-44)$. The importance of hydrogen consumption in interspecies hydrogen transfer during the degradation of amino acids has been investigated during the last decade $(30,33,34,35,39,45)$. The first step in the degradation of several amino acids (e.g., the branched-chain amino acids) is invariably an oxidative deamination that is usually followed by an oxidative decarboxylation of the resulting keto acid (1). Oxidative deaminations are always endergonic under standard conditions and therefore depend on the removal of the electrons produced in this step (35). It is known that these reactions are also possible through the Stickland reaction $(43,44)$ in addition to interspecies hydrogen transfer. In previous studies of the importance of interspecies hydrogen transfer for amino acid degradation in anaerobic mixed cultures, researchers obtained preliminary evidence that there are fermentative organisms that use acetate as an electron sink (33). In this paper we describe the properties of strain $30 \mathrm{~A}^{\mathrm{T}}$ (T = type strain), a new organism isolated from such cultures; in pure culture this organism can oxidatively deaminate alanine and the branched-chain amino acids by transferring the reducing equivalents to acetate with the production of butyrate as the reduced end product.

${ }^{*}$ Corresponding author. Present address: University of Akureyri, P.O. Box 224, IS-602, Akureyri, Iceland. Phone: 35446 30900. Fax: 354 46 30998. Electronic mail address: J.Orlygsson@unak.is.

\section{MATERIALS AND METHODS}

Media and cultivation methods. The medium used in this study contained (per liter) $1.2 \mathrm{~g}$ of $\mathrm{NaCl}, 0.15 \mathrm{~g}$ of $\mathrm{CaCl}_{2} \cdot 2 \mathrm{H}_{2} \mathrm{O}, 0.4 \mathrm{~g}$ of $\mathrm{MgCl}_{2} \cdot 6 \mathrm{H}_{2} \mathrm{O}, 0.28 \mathrm{~g}$ of $\mathrm{Na}_{2} \mathrm{SO}_{4}, 0.3 \mathrm{~g}$ of $\mathrm{KCl}, 0.3 \mathrm{~g}$ of $\mathrm{NH}_{4} \mathrm{Cl}, 0.2 \mathrm{~g}$ of $\mathrm{KH}_{2} \mathrm{PO}_{4}, 2.35 \mathrm{~g}$ of $\mathrm{NaHCO}_{3}, 0.12$ $\mathrm{g}$ of $\mathrm{Na}_{2} \mathrm{~S} \cdot 9 \mathrm{H}_{2} \mathrm{O}, 0.001 \mathrm{~g}$ of resazurin, and $2.0 \mathrm{~g}$ of yeast extract. In addition, a trace elements solution ( $1 \mathrm{ml} /$ liter $)$ and a vitamin solution $(1 \mathrm{ml} / \mathrm{liter})$ were added to the medium. The trace elements solution contained (per liter) $1,500 \mathrm{mg}$ of $\mathrm{FeCl}_{2} \cdot 4 \mathrm{H}_{2} \mathrm{O}, 70 \mathrm{mg}$ of $\mathrm{ZnCl}, 100 \mathrm{mg}$ of $\mathrm{MnCl}_{2} \cdot 4 \mathrm{H}_{2} \mathrm{O}, 62 \mathrm{mg}$ of $\mathrm{H}_{3} \mathrm{BO}_{3}, 190 \mathrm{mg}$ of $\mathrm{CoCl}_{2} \cdot 6 \mathrm{H}_{2} \mathrm{O}, 17 \mathrm{mg}$ of $\mathrm{CuCl}_{2} \cdot 2 \mathrm{H}_{2} \mathrm{O}, 20 \mathrm{mg}$ of $\mathrm{NiCl}_{2} \cdot 6 \mathrm{H}_{2} \mathrm{O}, 30 \mathrm{mg}$ of $\mathrm{Na}_{2} \mathrm{MoO}_{4} \cdot 2 \mathrm{H}_{2} \mathrm{O}, 33 \mathrm{mg}$ of $\mathrm{Na}_{2} \mathrm{WO}_{4} \cdot 2 \mathrm{H}_{2} \mathrm{O}$, and $26 \mathrm{mg}$ of $\mathrm{Na}_{2} \mathrm{SeO}_{3} \cdot 5 \mathrm{H}_{2} \mathrm{O}$. The vitamin solution contained (per liter) $100 \mathrm{mg}$ of $p$-aminobenzoic acid, 100 $\mathrm{mg}$ of riboflavin, $200 \mathrm{mg}$ of thiamine, $200 \mathrm{mg}$ of nicotinic acid, $500 \mathrm{mg}$ of pyridoxamine, $100 \mathrm{mg}$ of cobalamin, $20 \mathrm{mg}$ of biotin, $50 \mathrm{mg}$ of folic acid, $100 \mathrm{mg}$ of lipoic acid, and $100 \mathrm{mg}$ of pantothenic acid.

The medium was prepared as described by Nanninga and Gottschal (33). Growth experiments were performed in $15-\mathrm{ml}$ tubes or $118-\mathrm{ml}$ bottles sealed with butyl rubber stoppers. The gas phase consisted of $\mathrm{N}_{2}$ and $\mathrm{CO}_{2}(80: 20, \mathrm{vol} / \mathrm{vol})$, and the $\mathrm{pH}$ of the medium was 7.0. Most substrates were added from autoclaved stock solutions; the exceptions were some heat-sensitive compounds, which were filter sterilized.

Growth experiments with strain $30 \mathrm{~A}^{\mathrm{T}}$ were performed by using an inoculum from exponentially grown cultures containing leucine $(20 \mathrm{mM})$ and acetate $(30$ $\mathrm{mM}$ ). The inoculum size was $2 \%$ of the fresh culture volume, and the temperature was $37^{\circ} \mathrm{C}$. When strain $30 \mathrm{~A}^{\mathrm{T}}$ was cocultured with Methanobacterium formicicum or Desulfovibrio sp. strain DK81, the experimental bottles were inoculated with equal volumes of the hydrogen consumer and the producer, and the inoculum size was $5 \%$. M. formicicum was preincubated in the presence of $\mathrm{H}_{2}-\mathrm{CO}_{2}(80: 20)$, and Desulfovibrio sp. strain DK81 was pregrown in the presence of $5 \mathrm{mM}$ lactate and $10 \mathrm{mM}$ sulfate. In one case strain $30 \mathrm{~A}^{\mathrm{T}}$ was inoculated into a culture of $M$. formicicum growing in the presence of $\mathrm{H}_{2}-\mathrm{CO}_{2}(80: 20)$ that also contained leucine $(20 \mathrm{mM})$ and acetate $(30 \mathrm{mM})$ in the medium. Before strain $30 \mathrm{~A}^{\mathrm{T}}$ was added, the $\mathrm{H}_{2}-\mathrm{CO}_{2}$ gas phase was replaced with $\mathrm{N}_{2}-\mathrm{CO}_{2}(80: 20)$.

The purity of strain $30 \mathrm{~A}^{\mathrm{T}}$ was checked regularly by using $2 \%$ agar plates containing $20 \mathrm{mM}$ leucine- $30 \mathrm{mM}$ acetate as the substrate. Cysteine hydrochloride $(0.025 \%)$ was also used to reduce the medium. The bacterium was maintained by regular transfers (every 2 to 3 weeks) in a liquid medium containing 20 $\mathrm{mM}$ leucine $-30 \mathrm{mM}$ acetate as the substrate.

Source and isolation of strain $30 \mathrm{~A}^{\mathrm{T}}$. Strain $30 \mathrm{~A}^{\mathrm{T}}$ was isolated from a bioreactor at the purification plant of the AVEBE potato starch factory in De Krim, The Netherlands (33). The agar shake culture method (36) was used with leucine and acetate as the substrates for isolation.

Morphological characterization. Log-phase cells were fixed in $3 \%$ glutaraldehyde in $100 \mathrm{mM}$ sodium cacodylate buffer $\left(\mathrm{pH} \mathrm{7.2)}\right.$ for $2 \mathrm{~h}$ at $0^{\circ} \mathrm{C}$. The cells were post fixed with a mixture containing $1 \% \mathrm{OsO}_{4}$ and $5 \% \mathrm{~K}_{2} \mathrm{Cr}_{2} \mathrm{O}_{7}(2: 1)$. For sectioning, the cells were dehydrated in a series of ethanol solutions and embedded in Epon 812 . Whole cells were negatively stained with $1 \%$ uranyl acetate. A Philips model CM10 electron microscope was used to view the samples. 
Physiological and biochemical tests. The optimum temperature and temperature range were determined by using $20 \mathrm{mM}$ leucine- $30 \mathrm{mM}$ acetate as the substrate. The optical densities at $660 \mathrm{~nm}$ were used to calculate the maximum growth rate. To assess growth at different $\mathrm{pH}$ values, the medium was prepared without bicarbonate and with only $\mathrm{N}_{2}$ in the gas phase. The medium was buffered $(30 \mathrm{mM}$ ) with Tris-hydrochloride ( $\mathrm{pH} 5.0$ to 5.9 ), sodium phosphate ( $\mathrm{pH} 6.1$ to 7.8 ), and sodium citrate ( $\mathrm{pH} 8.2$ and higher) buffers. The concentrations of various energy sources and electron acceptors used in utilization tests were 20 and $30 \mathrm{mM}$, respectively.

To determine the Gram character we used the method described by Gregersen (14) and the $\mathrm{KOH}$ method (6).

$16 S$ rRNA gene sequence analysis. DNA was extracted from cells by the method of Lawson et al. (24). The 16S rRNA gene was amplified as described previously (18) and was purified by using a Prep-A-Gene kit (Bio-Rad) according to the manufacturer's instructions. The sequence of the $16 \mathrm{~S}$ ribosomal DNA fragment was determined by using a Taq DyeDeoxy terminator cycle sequencing kit (Applied Biosystems) and an Applied Biosystems model 373A automated sequencer. Phylogenic analyses were performed by using the PHYLIP package (11). A distinct matrix was obtained by using the DNASIST program, and a phylogenic tree was constructed by using the neighbor-joining method and the NEIGHBOR program. The stability of the relationships was assessed by the bootstrap method with the SEQBOOT, DNASIST, NEIGHBOR, and CONDENSE programs.

DNA base composition. The $\mathrm{G}+\mathrm{C}$ content of strain $30 \mathrm{~A}^{\mathrm{T}}$ was determined by the thermal denaturation method by using a Gilford model 2600 specrophotometer equipped with a model 2527 thermoprogrammer and was calculated by using the equation of Marmur and Doty (26), as modified by De Ley (8). Escherichia coli $\mathrm{K}-12$ strain DSM $485(\mathrm{G}+\mathrm{C}$ content, $51.7 \mathrm{~mol} \%)$ was used as the control.

Cytochromes. The presence of cytochromes was investigated by recording air-oxidized-versus-dithionate-reduced spectra of whole cells with a Shimadzu model UV-1601 UV-visible spectrophotometer.

Analytical procedures. The supernatants of outgrown cultures were used to analyze the various substrates and end products. Ammonium and formate contents were determined by colorimetric assays as described by Richterich (37) and Lang and Lang (23), respectively. Gas chromatographic methods were used to analyze volatile and nonvolatile fatty acids (33) and alcohols (21), as well as hydrogen and methane (13). The amino acids were analyzed by high-performance liquid chromatography (HPLC) by using phthalaldehyde as the derivatization agent (29). The amounts of cell carbon and total organic carbon were determined with a Shimadzu modeI TC-500 carbon analyzer by using biphthalate as the standard for dissolved organic carbon. Cell densities were determined by determining the optical densities at $660 \mathrm{~nm}$ in a 1-cm cuvettes containing cultures with a Vitalab colorimeter (Vital Scientific, Dieren, The Netherlands).

Nucleotide sequence accession number. The partial 16S rRNA gene sequence of strain $30 \mathrm{~A}^{\mathrm{T}}$ has been deposited in the EMBL data library under accession number X79862.

\section{RESULTS}

Source and isolation of strain $30 \mathrm{~A}^{\mathbf{T}}$. In a previous mixedculture study, Nanninga and Gottschal (33) presented evidence that valine- and leucine-fermenting bacteria depend on acetate as an external electron acceptor. A strictly anaerobic, rodshaped, amino acid-fermenting bacterium was isolated from the mixed cultures; this organism, strain $30 \mathrm{~A}^{\mathrm{T}}$, originated from a bioreactor at a purification plant at the AVEBE potato starch factory in De Krim, The Netherlands. Pure cultures of strain $30 \mathrm{~A}^{\mathrm{T}}$ were obtained from a serial dilution by using the agar shake culture method (36) with $20 \mathrm{mM}$ leucine- $30 \mathrm{mM}$ acetate as the substrate. On the basis of its morphological and basic physiological properties (see below), strain $30 \mathrm{~A}^{\mathrm{T}}$ was tentatively identified as a Clostridium sp. strain.

Cytological properties. Clostridium sp. strain $30 \mathrm{~A}^{\mathrm{T}}$ cells were straight rods ( 1 by $6 \mu \mathrm{m}$ ) that occurred as single cells, sometimes in pairs, and rarely in chains (Fig. 1A). The cells were nonmotile, and flagella were not observed in preparations containing negatively stained cells. Spore formation was not observed. Boiling $(10 \mathrm{~min})$ did not induce spore formation. The cells exhibited a cell wall structure typical of gram-positive organisms (Fig. 1B). Large inclusions were commonly seen in the cytoplasm (Fig. 1A), and a very thin (7-nm) S-layer was observed (Fig. 1C). The cell wall was $25 \mathrm{~nm}$ thick. Dithionitereduced-versus-air-oxidized difference spectra of whole cells grown on leucine and acetate did not yield evidence that cytochromes were present (data not shown).
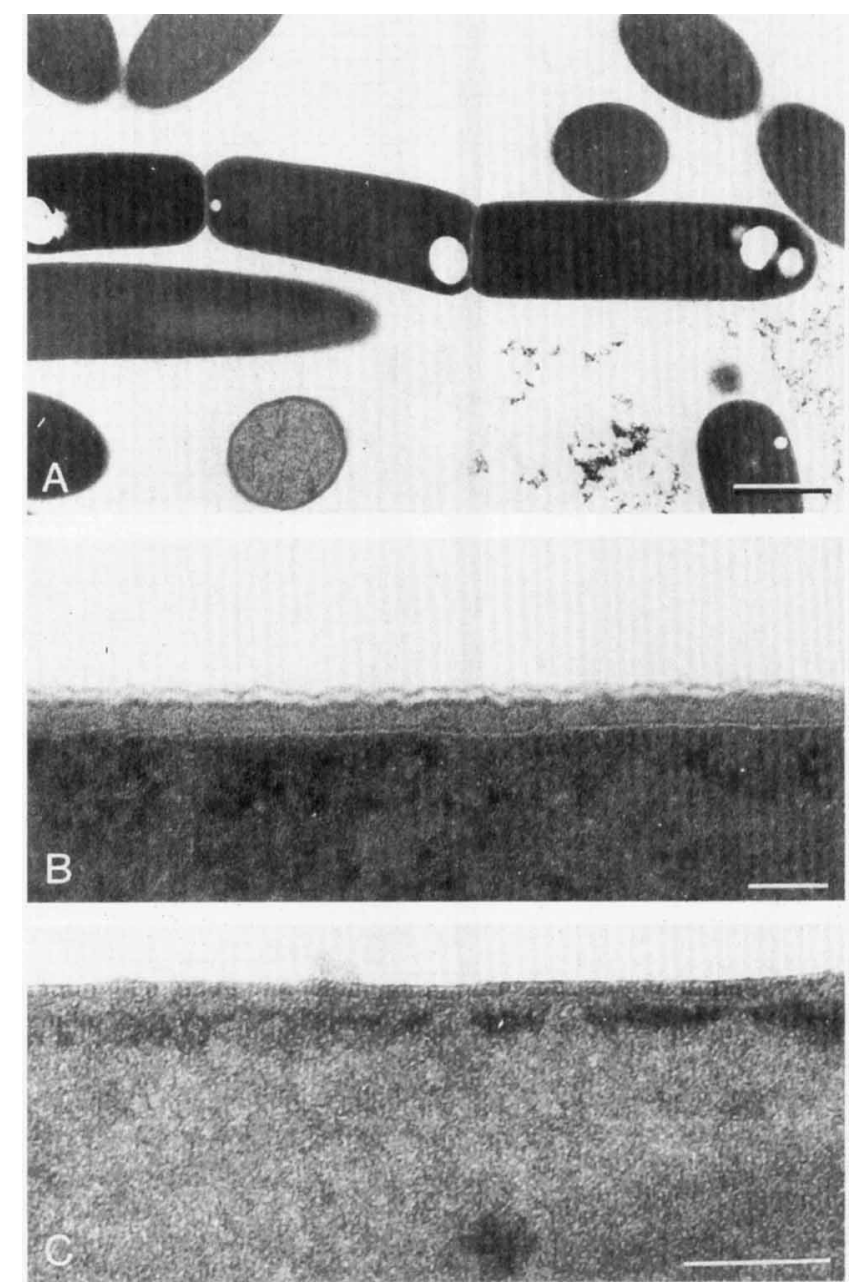

FIG. 1. Electron micrographs of exponentially grown cells of Clostridium sp. strain $30 \mathrm{~A}^{\mathrm{T}}$. (A) Thin section showing three cells attached together. Bar $=1 \mu \mathrm{m}$. (B) Thin section showing the typical gram-positive cell wall structure. Bar $=0.1$ $\mu \mathrm{m}$. (C) Negatively stained cell showing the thin S-layer. Bar $=0.1 \mu \mathrm{m}$.

16S rRNA sequence analysis. The partial 16S rRNA gene sequence of strain $30 \mathrm{~A}^{\mathbf{T}}$ that we determined consisted of 1,500 nucleotides, which represented approximately $97 \%$ of the total rRNA molecule. This new sequence was compared with a data set containing more than 300 sequences of clostridia and other low-G $+\mathrm{C}$-content gram-positive bacteria. Sequence similarity calculations revealed that the closest relatives of strain $30 \mathrm{~A}^{\mathrm{T}}$ are members of Clostridium group I. Figure 2 is a phylogenic tree that was constructed from a matrix of calculated evolutionary distances and shows the position of strain $30 \mathrm{~A}^{\mathrm{T}}$ within Clostridium group I and related organisms. The $\mathrm{G}+\mathrm{C}$ content of Clostridium sp. strain $30 \mathrm{~A}$ was $29 \mathrm{~mol} \%$.

Physiology. The dynamics of growth in batch culture and the formation of fermentation products by Clostridium sp. strain $30 \mathrm{~A}^{\mathrm{T}}$ grown on $20 \mathrm{mM}$ leucine- $30 \mathrm{mM}$ acetate and on leucine alone are shown in Fig. $3 \mathrm{~A}$ and $\mathrm{B}$, respectively. Only a little growth occurred on leucine alone (Fig. 3B), whereas good growth (maximum growth rate, $0.11 \mathrm{~h}^{-1}$ ) occurred on the leucine-acetate mixture (Fig. 3A). Leucine was degraded to isovalerate, $\mathrm{CO}_{2}, \mathrm{H}_{2}$, and $\mathrm{NH}_{3}$ with the concomitant reduction of acetate to butyrate. The ammonium concentration was 17.5 $\mathrm{mM}$ at the end of the experiment $(100 \mathrm{~h})$ for the leucineacetate mixture, and all of the leucine had been fermented. 


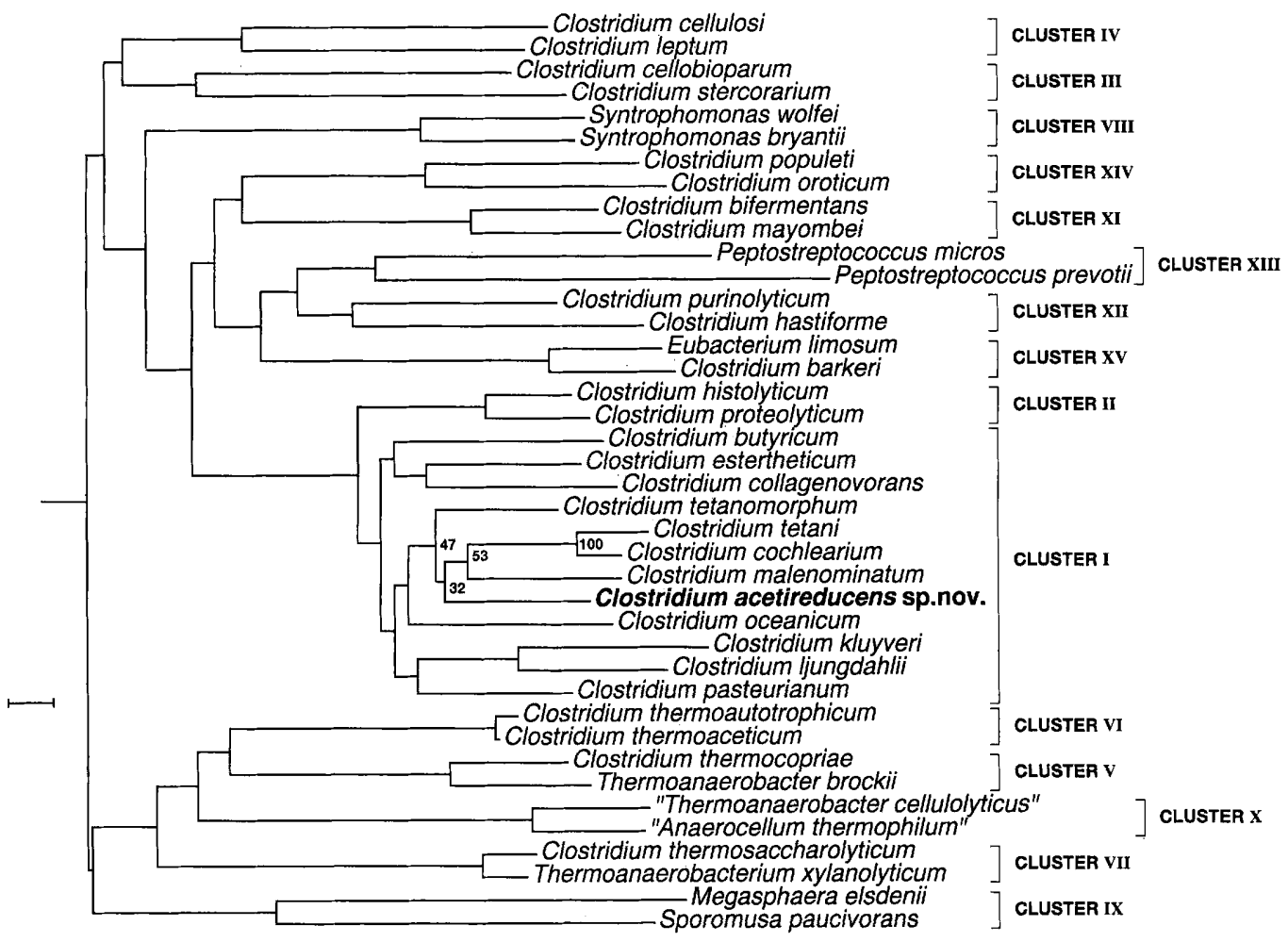

FIG. 2. Phylogenetic tree showing the position of $C$. acetireducens $30 \mathrm{~A}^{\mathrm{T}}$ within Clostridium group I. The Clostridium clusters shown are the clusters described by Collins et al. (7). The position of the root was determined by using Fusobacterium nucleatum as an outgroup. Bootstrap values are indicated at the branch points for the closest relatives of $C$. acetireducens. Scale bar $=1 \%$ divergence.

Addition of acetate $(14 \mathrm{mM})$ to bottles incubated for $85 \mathrm{~h}$ with leucine alone resulted in immediate degradation of the leucine and reduction of the acetate to butyrate (Fig. 3B).

Acetate was also required for the degradation of valine, isoleucine, and alanine, whereas serine, threonine, and pyruvate could be completely degraded without acetate. During growth on serine, threonine, and pyruvate more biomass (15 to $40 \%$ ) was produced in the presence of acetate than in the absence of acetate. Growth also occurred on peptone. Keto acid intermediates obtained from amino acid degradation, including $\alpha$-ketobutyrate, $\alpha$-ketoisocaproate, $\alpha$-keto-3-methylvalerate, and $\alpha$-ketoisovalerate, could be partially degraded when they were used as single carbon and energy sources (Table 1). Complete degradation of these substrates occurred when acetate was included in the medium. Leucine and $\alpha$-ketoisocaproate were degraded to isovalerate, whereas butyrate was the only volatile fatty acid found during pyruvate metabolism (Table 1). Serine was degraded to formate, acetate, and large amounts of butyrate, whereas threonine was converted predominantly to propionate and, to lesser extents, to 2-aminobutyrate and glycine. The keto acids were all decarboxylated to their respective fatty acids. Thus, $\alpha$-ketobutyrate, $\alpha$-keto-3methylvalerate, and $\alpha$-ketoisovalerate yielded propionate, 2-methylbutyrate, and isobutyrate, respectively. Relatively high amounts of hydrogen $(>0.25 \mathrm{~mol} / \mathrm{mol}$ of substrate $)$ were produced with all of the substrates except serine, threonine, and pyruvate; with the latter three substrates $<0.1$ mol of hydrogen per mol of substrate was produced. Other substrates that were tested but were not utilized were ethanol, citrate, succinate, acetate, propionate, fructose, lactose, glucose, $\mathrm{H}_{2}$-acetate, and all other amino acids. No degradation of leucine was observed when Clostridium sp. strain $30 \mathrm{~A}^{\mathrm{T}}$ was cocultured with hydro- gen-consuming bacteria or in the presence of glycine or proline, amino acids which serve as electron acceptors in the Stickland reaction. In addition, Clostridium $\mathrm{sp}$. strain $30 \mathrm{~A}^{\mathrm{T}}$ was not capable of using fumarate, nitrate, nitrite, sulfite, sulfate, or oxygen as an electron acceptor. Yeast extract was required for growth.

The optimum temperature for growth of Clostridium sp. strain $30 \mathrm{~A}^{\mathrm{T}}$ ranged from 39 to $43^{\circ} \mathrm{C}$, and no growth was observed at temperatures below $20^{\circ} \mathrm{C}$ and above $47^{\circ} \mathrm{C}$ (Fig. $4 \mathrm{~A}$ ). The optimum $\mathrm{pH}$ was between 6.4 and 7.6, and no growth was observed at $\mathrm{pH}$ values below 5.8 and above 8.5 (Fig. 4B).

\section{DISCUSSION}

Comparison of Clostridium sp. strain $30 \mathrm{~A}^{\mathrm{T}}$ with other clostridia. (i) $16 \mathrm{~S}$ rRNA sequence analysis. It was evident from both the distance calculations and the treeing analysis that Clostridium sp. strain $30 \mathrm{~A}^{\mathrm{T}}$ is phylogenetically closely related to members of Clostridium group I (sensu Johnson and Francis) (7). Within this group strain $30 \mathrm{~A}^{\mathrm{T}}$ forms a distinct line that is separate from all previously recognized clostridial species (data not shown). The closest known relatives of Clostridium sp. strain $30 \mathrm{~A}^{\mathrm{T}}$ are Clostridium cochlearium, Clostridium tetani, Clostridium malenominatum, and Clostridium tetanomorphum, although sequence divergence values (approximately 6 to $8 \%$ ) and the results of bootstrap analyses indicate that this association is not particularly significant (Fig. 2). Clostridium group I includes the type species of the genus Clostridium, Clostridium butyricum, and it is now generally, if not universally, recognized that this cluster of organisms represents the genus Clostridium sensu stricto (7). Although spores were not observed in Clostridium sp. strain $30 \mathrm{~A}^{\mathrm{T}}$, there is no doubt from the phyloge- 

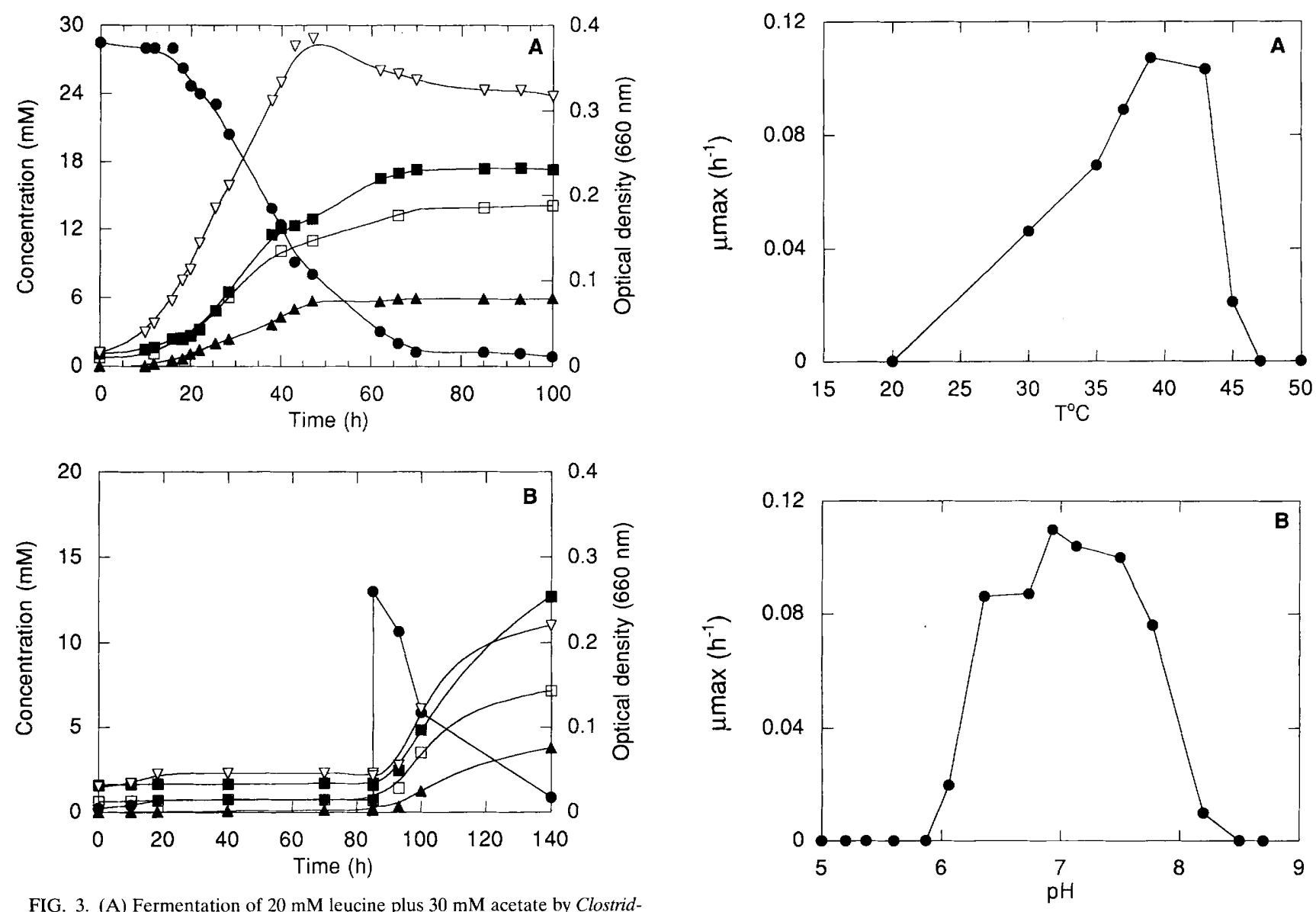

FIG. 3. (A) Fermentation of $20 \mathrm{mM}$ leucine plus $30 \mathrm{mM}$ acetate by Clostridium sp. strain $30 \mathrm{~A}^{\mathrm{T}}$. (B) Fermentation of $20 \mathrm{mM}$ leucine. After $85 \mathrm{~h}, 14 \mathrm{mM}$ acetate was added to the culture. The amounts of end products in control bottles (containing yeast extract with and without acetate) were subtracted. At the end of the experiments, less than $0.1 \mathrm{mM}$ leucine remained in the incubation bottles, as determined by an HPLC analysis. Symbols: $\bullet$, acetate; $\square$, butyrate; $\mathbf{\square}$, isovalerate; $\boldsymbol{\Lambda}$, hydrogen; $\nabla$, optical density at $660 \mathrm{~nm}$. The amount of hydrogen detected in the gas phase (millimoles of $\mathrm{H}_{2}$ per liter of gas in the headspace) was expressed in millimoles per liter of culture liquid in the culture flask.

netic evidence that this bacterium should be placed in the genus Clostridium sensu stricto. Several other species currently considered members of genus Eubacterium (e.g., Eubacterium budayi, Eubacterium delafieldii, Eubacterium moniliforme, Eubacterium multiforme, Eubacterium nitritogenes, and Eubacterium tarantellus) also lack spores and phylogenetically are

FIG. 4. Growth rate of strain $30 \mathrm{~A}^{\mathrm{T}}$ as a function of temperature $(\mathrm{A})$ and $\mathrm{pH}$ (B) when the organism was grown in sodium bicarbonate buffer at $\mathrm{pH} 7 . \mathrm{T}$, temperature; $\mu$ max, maximum growth rate.

members of Clostridium group I. However, we note that $E$ bacterium limosum, the type species of the genus Eubacterium, is phylogenically far removed from Clostridium group I and is a member of Clostridium cluster XV (7). Assignment of Clostridium sp. strain $30 \mathrm{~A}^{\mathrm{T}}$ to the non-spore-forming genus Eubacterium can therefore be ruled out.

(ii) Amino acid utilization. Clostridium sp. strain $30 \mathrm{~A}^{\mathrm{T}}$ is able to degrade six different amino acids to various fatty acids, carbon dioxide, hydrogen, and ammonia, and acetate is re-

TABLE 1. Products formed during growth of strain $30 \mathrm{~A}^{\mathrm{T}}$ on leucine plus acetate, $\alpha$-ketoisocaproate, $\alpha$-ketoisocaproate plus acetate, pyruvate, and pyruvate plus acetate ${ }^{a}$

\begin{tabular}{|c|c|c|c|c|c|c|c|}
\hline \multirow{2}{*}{ Substrate(s) ${ }^{b}$} & \multicolumn{5}{|c|}{ Concn of the following products $(\mathrm{mM})$} & \multicolumn{2}{|c|}{$\%$ Recovery } \\
\hline & Acetate $^{c}$ & Butyrate & Isovalerate & Hydrogen & Cell carbon $^{d}$ & Carbon & Electrons \\
\hline Leucine $(20 \mathrm{mM})+$ acetate $(30 \mathrm{mM})$ & 1.8 & 11.2 & 17.5 & 7.3 & 16.3 & 94.3 & 80.5 \\
\hline$\alpha$-Ketoisocaproate $(20 \mathrm{mM})$ & & & 6.5 & 3.9 & 8.5 & 98.9 & 80.0 \\
\hline$\alpha$-Ketoisocaproate $(20 \mathrm{mM})+$ acetate $(30 \mathrm{mM})$ & 12.0 & 8.5 & 16.9 & 6.9 & 22.5 & 101.0 & 90.0 \\
\hline Pyruvate $(20 \mathrm{mM})$ & & 7.5 & & 0.1 & 10.5 & 95.8 & 82.3 \\
\hline Pyruvate $(20 \mathrm{mM})+$ acetate $(30 \mathrm{mM})$ & 20.1 & 11.5 & & 0.1 & 13.5 & 101.9 & 84.0 \\
\hline
\end{tabular}

${ }^{a}$ The values obtained for fermentation products when yeast extract was used were subtracted from the values obtained in all incubation experiments. Samples were obtained after incubation for 1 month, and the values are the means obtained from two experiments.

${ }^{b}$ Most substrates were completely degraded; the only exception was $\alpha$-ketoisocaproate when it was used as the sole substrate ( $8 \mathrm{mM}$ was degraded).

${ }^{c}$ Acetate concentrations left in the experimental bottles.

${ }^{d}$ Total organic carbon concentrations in pellets of the cultures. 
quired as an electron acceptor during degradation of the branched-chain amino acids and alanine. To our knowledge, there are no other fermentative bacteria that have been described that grow exclusively by using acetate as an electron acceptor for growth on these amino acids. Dependence on interspecies hydrogen transfer is observed more commonly (for example, through metabolic coupling to methanogenesis $[15,34,35]$ or sulfate reduction $[33,39]$ or by means of the Stickland reaction $[43,44])$. Clostridium sp. strain $30 \mathrm{~A}^{\mathrm{T}}$ appeared to be entirely dependent on the reduction of acetate for the degradation of alanine and the branched-chain amino acids. On the basis of these highly specialized physiological characteristics, Clostridium sp. strain $30 \mathrm{~A}^{\mathrm{T}}$ does not belong to any of the previously described Clostridium species. Clostridium sp. strain $30 \mathrm{~A}^{\mathrm{T}}$ does not utilize sugars like $C$. butyricum and Clostridium tyrobutyricum, two species that are known to use acetate as an electron acceptor during growth on mannitol and lactate, respectively (see below). In addition to the phylogenetic differences of $C$. cochlearium, $C$. tetanomorphum, $C$. malenominatum, and $C$. tetani, these bacteria differ from strain $30 \mathrm{~A}^{\mathrm{T}}$ in several aspects. Most importantly, they do not require acetate for growth. $C$. tetani and $C$. tetanomorphum are both saccharolytic and proteolytic $(17,38)$; these two bacteria can also degrade amino acids that are not degraded by Clostridium sp. strain $30 \mathrm{~A}^{\mathrm{T}}$, including glutamate, glutamine, and histidine $(17,38)$.

(iii) Use of acetate as an external electron acceptor. Acetate has been reported to be used as an external electron acceptor by some bacteria but not by clostridia growing on amino acids. For example, Kutzner (20) observed that acetate had some positive effects on degradation of mannitol by $C$. tyrobutyricum and $C$. butyricum. This author suggested that acetate was an electron acceptor that scavenged electrons that could not be transferred to protons and released as hydrogen. Heyndrick et al. (16) showed that acetate was indeed used as an electron acceptor by $C$. butyricum; the presence of acetate was even crucial for complete degradation of mannitol. The versatile bacterium Eubacterium limosum has been reported to use acetate as an external acceptor during growth on lactate and methanol plus carbon dioxide $(2,25)$, and Genthner et al. (12) have suggested that this bacterium might reduce acetate to butyrate during growth on isoleucine. However, the amount of acetate converted to butyrate in that study was very low compared with the amount found in our investigation and was three times less than the amount required for stoichiometric electron transfer from isoleucine to acetate. It has been reported that Clostridium kluyveri requires acetate to degrade ethanol $(2,19)$. Finally, Clostridium beijerinckii degrades lactate only in the presence of acetate, which is reduced to butyrate (5).

The most obvious pathway for the reduction of acetate to butyrate is the classical butyrate pathway used by clostridia (1). Before acetate enters this pathway, it has to be activated to acetyl coenzyme A at the cost of 1 ATP. One-half of this energy is regained in the pathway leading to butyrate. On the basis of our results, it can be concluded that there is an absolute requirement for acetate for degradation of branchedchain amino acids and alanine (data shown for leucine). We found that the keto acid intermediates in amino acid degradation ( $\alpha$-ketobutyrate, $\alpha$-ketoisocaproate, $\alpha$-keto-3-methylvalerate, and $\alpha$-ketoisovalerate) were only partially degraded unless acetate was included in the medium (Table 1). When substrates that could be completely degraded in the absence of acetate (serine, threonine, and pyruvate) were used, more biomass was produced when acetate was included in the medium. The fact that formation of butyrate is indeed favored in strain
$30 \mathrm{~A}^{\mathrm{T}}$ was observed when this organism was grown on pyruvate. Instead of producing the energetically more favorable end product acetate (1 mol of ATP produced per mol of pyruvate), the organism produced only butyrate $(0.5 \mathrm{~mol}$ of ATP produced per mol of pyruvate) (Table 1). The observed fermentation patterns of Clostridium sp. strain $30 \mathrm{~A}^{\mathrm{T}}$ suggest that leucine is deaminated to $\alpha$-ketoisocaproate, which is further decarboxylated to isovalerate. The reducing equivalents produced during the deamination step are used to reduce acetate to butyrate.

The sequence of steps may be summarized as follows:

$$
\text { leucine }+\mathrm{H}_{2} \mathrm{O} \rightarrow \alpha \text {-ketoisocaproate }{ }^{-} \Delta \mathrm{G}^{0 \prime} \quad \text { (kJ/reaction) }
$$$$
+\mathrm{NH}_{4}^{+}+2(\mathrm{H})
$$

$$
\begin{aligned}
& \alpha \text {-ketoisocaproate }+2 \mathrm{H}_{2} \mathrm{O} \rightarrow \text { isovalerate }^{-} \\
&+\mathrm{HCO}_{3}^{-}+\mathrm{H}^{+}+\mathrm{H}_{2} \\
& \text { acetate }^{-}+0.5 \mathrm{H}^{+}+2(\mathrm{H}) \rightarrow 0.5 \text { butyrate }^{-}
\end{aligned}
$$$$
+\mathrm{H}_{2} \mathrm{O}
$$

Thus, the overall reaction is:

$$
\begin{aligned}
\text { leucine } & + \text { acetate } \\
& +2 \mathrm{H}_{2} \mathrm{O} \rightarrow \text { isovalerate } \\
& +0.5 \text { butyrate } \\
& +0.5 \mathrm{HH}_{4}^{+}+\mathrm{HCO}_{3}{ }^{-}
\end{aligned}
$$

The $\Delta \mathrm{G}^{0^{\prime}}$ values were calculated on the basis of data of Thauer et al. (40).

Further work is now under way to investigate what metabolic pathway is used for the conversion of acetate to butyrate and to determine if any additional energy is gained in this pathway.

Description of Clostridium acetireducens sp. nov. Clostridium acetireducens (a.ce.ti.re.dúcens. L. neut. n acetum, vinegar; L. pres. parti. reducens, reducing; L. neut. adj. acetireducans, vinegar or acetic acid reducing). The main characteristic of the species is its ability to use acetate as an electron acceptor during growth on leucine, valine, isoleucine, and alanine. The reduced product is butyrate.

C. acetireducens cells are strictly anaerobic, straight rods that are $1 \mu \mathrm{m}$ in diameter and $6 \mu \mathrm{m}$ long. The organism is nonmotile, and no flagella or spores are observed. Gram reaction positive, as confirmed by electron micrographs showing a thin S-layer.

Growth occurs at $\mathrm{pH} 6.0$ to 8.2 , and the optimal $\mathrm{pH}$ is 6.4 to 7.6. The temperature range for growth is 30 to $45^{\circ} \mathrm{C}$, and the optimal temperature is 39 to $43^{\circ} \mathrm{C}$.

C. acetireducens requires yeast extract for growth. It grows on leucine, valine, isoleucine, and alanine only in the presence of acetate. Other substrates utilized are peptone (a pancreatic digest of casein), serine, threonine, $\alpha$-ketobutyrate, $\alpha$-ketoisocaproate, $\alpha$-keto-3-methylvalerate, and $\alpha$-ketoisovalerate. $C$. acetireducens does not grow on saccharides, citrate, succinate, propionate, $\mathrm{H}_{2}$-acetate, ethanol, or other amino acids, and it cannot use fumarate, sulfate, sulfite, nitrate, nitrite, or oxygen as an electron acceptor.

Type strain. Strain 30A ( = DSM 7310) is the type strain of C. acetireducens. $\mathrm{G}+\mathrm{C}$ content of $C$. acetireducens is $28.5 \mathrm{~mol} \%$ (as determined by the thermal denaturation method).

\section{ACKNOWLEDGMENTS}

We thank K. Sjollema for performing the electron microscopy. We thank Bo Svensson for financial support. This work was sponsored in 
part by the Swedish Institute and by European Community Microbial Diversity Network grant ERBCHRXCT 930194.

\section{REFERENCES}

1. Andreesen, J. R., H. Bahl, and G. Gottschalk. 1989. Introduction to the physiology and biochemistry of the genus Clostridium, p. 27-62. In N. P Minton and D. J. Clarke (ed.), Clostridia. Plenum Press, New York.

2. Barker, H. A. 1957. Bacterial fermentations. Wiley, New York.

3. Barker, H. A. 1981. Amino acid degradation by anaerobic bacteria. Annu. Rev. Biochem. 40:23-40.

4. Bentley, C. M., and E. A. Dawes. 1974. The energy-yielding reactions of Peptococcus prevotii, their behaviour on starvation and the role and regulation of threonine dehydratase. Arch. Microbiol. 100:363-387.

5. Bhat, J. C., and H. A. Barker. 1947. Clostridium lactoacetophilum nov. spec. and the role of acetic acid in the butyric acid fermentation of lactate. J. Bacteriol. 54:381-391.

6. Buck, J. D. 1982. Nonstaining (KOH) method for determination of Gram reactions of marine bacteria. Appl. Environ. Microbiol. 44:992-993.

7. Collins, M. D., P. A. Lawson, A. Willems, J. J. Cordoba, J. FernandezGarayzabal, P. Garcia, J. Cai, H. Hippe, and J. A. E. Farrow. 1994. The phylogeny of the genus Clostridium: proposal of five new genera and eleven new species combinations. Int. J. Syst. Bacteriol. 44:812-826.

8. De Ley, J. 1970. Reexamination of the association between melting point, buoyant density, and chemical base composition of nucleic acids. J. Bacteriol. 101:738-754.

9. Elsden, S. R., and M. G. Hilton. 1978. Volatile acid production from threonine, valine, leucine and isoleucine by clostridia. Arch. Microbiol. 117:165172 .

10. Elsden, S. R., and M. G. Hilton. 1979. Amino acid utilization patterns in clostridial taxonomy. Arch. Microbiol. 123:137-141.

11. Felsenstein, J. 1989. PHYLIP-phylogeny inference package (version 3.2). Cladistics 5:164-166.

12. Genthner, B. R. S., C. L. Davis, and M. P. Bryant. 1981. Features of rumen and sewage sludge strains of Eubacterium limosum, a methanol- and $\mathrm{H}_{2}$ $\mathrm{CO}_{2}$-utilizing species. Appl. Environ. Microbiol. 42:12-19.

13. Gerritse, J., F. Schut, and J. C. Gottschal. 1990. Mixed chemostat cultures of obligatory aerobic and fermentative or methanogenic bacteria under oxygenlimiting conditions. FEMS Microbiol. Lett. 66:87-94.

14. Gregersen, T. 1978. Rapid method for distinction of Gram-negative from Gram-positive bacteria. Eur. J. Appl. Microbiol. Biotechnol. 5:123-127.

15. Guangsheng, C., C. M. Plugge, W. Roelofsen, F. P. Houwen, and A. J. M. Stams. 1991. Selenomonas acidaminovorans sp. nov., a versatile thermophilic proton-reducing anaerobe with the ability to grow by decarboxylation of succinate to propionate. Arch. Microbiol. 157:169-175.

16. Heyndrick, H., P. De Vos, A. Speybrouck, and J. De Ley. 1989. Fermentation of mannitol by Clostridium butyricum: role of acetate as an external hydrogen acceptor. Appl. Microbiol. Biotechnol. 31:323-328.

17. Hippe, H., J. R. Andreesen, and G. Gottschalk. 1992. The genus Clostridium-nonmedical, p. 1800-1866. In A. Balows, H. G. Trüper, M. Dworkin, W. Harder, and K. H. Schleifer (ed.), The prokaryotes, vol. 2. SpringerVerlag, New York.

18. Hutson, R. A., D. E. Thompson, and M. D. Collins. 1993. Genetic interrelationships of saccharolytic Clostridium botulinum types $\mathrm{B}, \mathrm{E}$ and $\mathrm{F}$ and related clostridia as revealed by small subunit rRNA sequences. FEMS Microbiol. Lett. 108:103-110.

19. Kenealy, W. R., and D. M. Waselefsky. 1985 . Studies on the substrate range of Clostridium kluyveri; the use of propanol and succinate. Arch. Microbiol. 141:187-194.

20. Kutzner, H. J. 1963. Untersuchungen an Clostridien mit besonderer Berucksichtigung der für die Milchwirtschaft wichtigen Arten. Zentralbl. Bakteriol. Parasitenkd. Infektionskr. Hyg. Abt. 1 Orig. 191:441-450.

21. Laanbroek, H. J., H. J. Geerligs, L. Sijtsma, and H. Veldkamp. 1984. Competition for sulfate and ethanol among Desulfobacter, Desulfobulbus, and Desulfovibrio species isolated from intertidal sediments. Appl. Environ. Microbiol. 47:329-334.

22. Laanbroek, H. J., J. T. Lambers, W. M. De Vos, and H. Veldkamp. 1978. L-Aspartate fermentation by a free-living Campylobacter species. Arch. Microbiol. 117:109-114.
23. Lang, E., and H. Lang. 1972. Spezifische Farbreaction zum direkten Nachweis der Ameisensäure. Zeitung Anal. Chem. 260:8-10.

24. Lawson, P. A., S. E. Gharbia, H. N. Shah, and D. R. Clark. 1989. Recognition of Fusobacterium nucleatum subgroups FN-1, FN-2 and FN-3 by ribosomal RNA gene restriction patterns. FEMS Microbiol. Lett. 65:41-46.

25. Loubiere, P., and N. D. Lindley. 1991. The use of acetate as an additional cosubstrate improves methylotrophic growth of the acetogenic anaerobe Eubacterium limosum when $\mathrm{CO}_{2}$ fixation is rate limiting. J. Gen. Microbiol. 137:2247-2251.

26. Marmur, J., and P. Doty. 1962. Determination of the base composition of DNA from its thermal denaturation temperature. J. Mol. Biol. 5:109-118.

27. McInerney, M. J. 1988. Anaerobic hydrolysis and fermentation of fats and proteins, p. 373-415. In A. J. B. Zehnder (ed.), Biology of anaerobic microorganisms. John Wiley and Sons, New York.

28. Mead, G. C. 1971. The amino acid-fermenting clostridia. J. Gen. Microbiol. 67:47-56.

29. Mopper, K., and R. Dawson. 1986. Determination of amino acids in seawater. Recent chromatographic developments and future directions. Sci. Total Environ. 449:115-131.

30. Nagase, M., and T. Matuso. 1982. Interaction between amino-acid-degrading bacteria and methanogenic bacteria in anaerobic digestion. Biotechnol. Bioeng. 24:2227-2239.

31. Nanninga, H. J., W. J. Drent, and J. C. Gottschal. 1986. Major differences between glutamate-fermenting species isolated from chemostat enrichments at different dilution rates. FEMS Microbiol. Ecol. 38:321-329.

32. Nanninga, H. J., W. J. Drent, and J. C. Gottschal. 1987. Fermentation of glutamate by Selenomonas acidaminophila sp. nov. Arch. Microbiol. 147: 152-157.

33. Nanninga, H. J., and J. C. Gottschal. 1985. Amino acid fermentation and hydrogen transfer in mixed cultures. FEMS Microbiol. Ecol. 31:261-269.

34. Örlygsson, J., F. P. Houwen, and B. H. Svensson. 1993. Anaerobic degradation of protein and the role of methane formation in steady state thermophilic enrichment cultures. Swed. J. Agric. Ser. 23:45-54.

35. Örlygsson, J., F. P. Houwen, and B. H. Svensson. 1994. Influence of hydrogenotrophic methane formation on the thermophilic anaerobic degradation of protein and amino acids. FEMS Microbiol. Ecol. 13:327-334.

36. Pfenning, N. 1978. Rhodocyclus purpureus gen. nov. and sp. nov., a ringshaped, vitamin $\mathrm{B}_{12}$-requiring member of the family Rhodospirillaceae. Int. J. Syst. Bacteriol. 28:283-288.

37. Richterich, R. 1965. Klinische Chemie. Akademische Verlaggesellschaft, Frankfurt.

38. Smith, L. D. S. 1992. The genus Clostridium-medical, p. 1867-1878. In A. Balows, H. G. Trüper, M. Dworkin, W. Harder, and K. H. Schleifer (ed.), The prokaryotes, vol. 2. Springer-Verlag, New York.

39. Stams, A. J. M., and T. A. Hansen. 1984. Fermentation of glutamate and other compounds by Acidaminobacter hydrogenoformans gen. nov., sp. nov., an obligate anaerobe isolated from black mud. Studies with pure cultures and mixed cultures with sulfate reducing and methanogenic bacteria. Arch. Microbiol. 137:329-337.

40. Thauer, R. K., K. Jungermann, and K. Decker. 1977. Energy conservation in chemotrophic anaerobic bacteria. Bacteriol. Rev. 41:100-180.

41. Wallace, R. J. 1986. Catabolism of amino acids by Megasphaera elsdenii LC1. Appl. Environ. Microbiol. 51:1141-1143.

42. Whiteley, H. R. 1957. Fermentation of amino acids by Micrococcus aerogenes. J. Bacteriol. 74:324-330.

43. Wildenauer, F. X., and J. Winter. 1986. Fermentation of isoleucine and arginine by pure and syntrophic cultures of Clostridium sporogenes. FEMS Microbiol. Ecol. 38:373-379.

44. Winter, J., F. Schindler, and F. X. Wildenauer. 1987. Fermentation of alanine and glycine by pure and syntrophic cultures of Clostridium sporogenes. FEMS Microbial Ecol. 45:153-161.

45. Zindel, U., W. Freudenberg, M. Reith, J. R. Andreesen, J. Schnell, and F. Widdel. 1988. Eubacterium acidaminophilum sp. nov., a versatile amino aciddegrading anaerobe producing or utilizing $\mathrm{H}_{2}$ or formate. Arch. Microbiol. 150:254-266. 